\title{
IAMJ
}

INTERNATIONAL

AYURVEDIC

MEDICAL JOURNAL

\section{COMPARATIVE CLINICAL STUDY TO EVALUATE THE EFFICACY OF GEETAM AND CHANDRANULOMAVILOMA PRANAYAMA IN KRODHA}

\author{
Anagha T V', Anil Kumar Rai ${ }^{2}$, Raviprasad Hegde ${ }^{3}$ \\ ${ }^{1} 3^{\text {rd }}$ Year PGScholar \\ ${ }^{2}$ Professor and HOD, \\ ${ }^{3}$ Associate Professor \\ Dept. of Manovijnana Evam Manasaroga \\ Alvas Ayurveda Medical College, Moodbidri, D.K District, Karnataka-574227
}

Corresponding Author: dranaghatv@gmail.com

\section{https://doi.org/10.46607/iamj1209102021}

(Published Online: October 2021)

\section{Open Access}

(C) International Ayurvedic Medical Journal, India 2021

Article Received: 01/10//2021 - Peer Reviewed: 10/10/2021 - Accepted for Publication: 11/10/2021

\section{Check for updates}

\begin{abstract}
Krodha is a Manasika Vikara which can be assessed by Droha done by another person. Here is an attempt made to evaluate the efficacy of Geetam and Chandra Anuloma Viloma Pranayama in the management of Krodha. Forty subjects fulfilling the diagnostic and inclusion criteria were selected and randomly assigned into two groups. Group A was treated with Geetam, and Group B were treated with Chandra Anuloma Viloma Pranayama. The effect of treatment was assessed based on symptoms of Krodha, Intermittent explosive disorder and Buss and Perry Scale. Both Geetam and Chandra Anuloma Viloma Pranayama showed a statistically significant effect on the assessment criteria. On comparison between two groups, there is no statistically significant difference between Group A and Group B. Thus, the null hypothesis is rejected, and the alternative hypothesis (H1) is accepted i.e., There is an equivalent effect of both Geetam and Chandra Anuloma Viloma pranayama in the management of the Krodha.
\end{abstract}

Keywords: Geetam; Chandra Anuloma Viloma, Pranayama; Krodha; Aggression; Intermittent explosive disorder. 


\section{INTRODUCTION}

India has the largest adolescent population in the world, 253 million, and every fifth person is between 10 and 19 years. ${ }^{1}$ This is the most crucial period as it is the transitional stage between childhood and adulthood. Many Physical, Physiological behavioural changes occur during this period. Generally, aggressive behaviours progress from less to more severe throughout adolescent development. ${ }^{2}$ Aggression is overt behaviour that involves a threat or action that potentially or causes pain, withdrawal, or loss of resources. ${ }^{3}$ Adolescent aggression is an important focus for educators and parents owing to its relative stability over time and consistent link to a variety of negative outcomes later in adolescence, including delinquency, substance use, conduct problems, poor adjustment, and academic difficulties. Krodha is a Manasikavikara ${ }^{4}$ which can be assessed by Droha done by another person according to Dalhana 5 . As per Bhagavat Gita, Krodha leads to Buddhi Nasha and thereby destruction. ${ }^{6}$

Krodha is a Pittaja Vikara. ${ }^{7}$ So Pittasya upakrama can be adopted in Krodha. In Ashtanga Hrudaya, Acharya mentioned 'Geetam' as one of the Pittasya Upakrama. "Geetam Ganam" as per Arunadatta. ${ }^{8}$ Each Raga has a specific action on a specific Dosha. So, in this study, "Raga Purvi" is used as it pacifies Pitta Dosha. ${ }^{10}$ Geeta by Pitta Shamana property pacifies Pitta there by Krodha.

Pranayama is one of the eight limbs of Ashtanga Yoga. The word Pranayama means 'extension or expansion of the dimension of Prana. The Shivaswarodaya, an ancient treatise advises quieter, passive activities (Soumya Karya) when the left nostril (Ida/Chandra Swara) is dominant and engage in challenging and exertional activities (roudra karya) when the right nostril (Pingala/Surya Swara) is dominant and to relax or meditate when flow through both nostrils is equal (Sushumna Swara). ${ }^{11}$ In this study Chandra Anuloma Viloma Pranayama is selected because Krodha is a Pittaja vikara. By the virtue of cooling down or parasympathetic effect in the body, it pacifies Pitta and in turn, helps to control Krodha. Here, an attempt is made to compare the efficacy of Geetam and Chandra Anuloma Viloma Pranayama in Krodha.

\section{AIM AND OBJECTIVES}

- To evaluate the effect of Geetam in the management of Krodha.

- To evaluate the effect of Chandra Anuloma Viloma Pranayama in the management of Krodha.

- To compare the effect of Geetam and Chandra Anuloma Viloma Pranayama in the management of Krodha

\section{MATERIALS AND METHODS}

Study Design: - An open randomized comparative clinical study of two groups consisting of twenty subjects in each group.

Sample Size - A separate case proforma was prepared and screening was done by giving questionnaires. Forty subjects fulfilling the diagnostic and inclusion criteria with history taking, physical signs and symptoms were selected. The assessment parameters obtained was scored and statistically analysed.

\section{INCLUSION CRITERIA}

- Subjects of adolescent age (10-19yrs), irrespective of gender, caste, and creed.

- Subjects presenting with general features of Intermittent explosive disorder.

\section{EXCLUSION CRITERIA}

- Subjects suffering from other Psychiatric Diseases.

- Subjects suffering from other organic diseases.

\section{ASSESSMENT CRITERIA}

Diagnosis and improvement in signs and symptoms of the condition was made according to symptoms of Intermittent Explosive Disorder and Buss and Perry Scale

1) Buss and Perry Scale

2) Symptoms of IED

- Physical aggression

- Verbal Aggression

- Aggressive behaviour is grossly disproportionate to the magnitude of the psychosocial stressors

- The recurrent aggressive outbursts cause either marked distress in the individual or impairment in occupational or interpersonal functioning. 


\section{DIAGNOSTIC CRITERIA}

A. Recurrent outbursts that demonstrate an inability to control impulses, including either of the following: Verbal aggression (tantrums, verbal arguments, or fights) or physical aggression that occurs twice in a week-long period for at least three months and does not lead to the destruction of property or physical injury (Criterion A1) - Three outbursts that involve injury or destruction within a year-long period (Criterion A2)

B. Aggressive behaviour is grossly disproportionate to the magnitude of the psychosocial stressors (Criterion B).

C. The outbursts are not premeditated and serve no premeditated purpose (Criterion C).

D. The individual must be at least six years old (Criterion D)

E. The recurrent outbursts cannot be explained by another mental disorder and are not the result of another medical disorder or substance use (Criterion E).

- Two separate criteria for types of aggressive outbursts (A1 and A2) which have empirical support

- Criterion A1: Episodes of verbal and/or nondamaging, nondestructive, or non-injurious physical assault that occur, on average, twice weekly for three months. These could include temper tantrums, tirades, verbal arguments/fights, or assault without damage. This criterion includes high frequency/low-intensity outbursts.

- Criterion A2: More severe destructive/assaultive episodes which are more infrequent and occur, on average, three times within twelve months. These could be destroying an object without regard to value, assaulting an animal or individual. This criterion includes high-intensity/low-frequency outbursts.

\section{PLAN FOR STUDY}

The cases were selected as per signs and symptoms of the intermittent explosive disorder.

Table 1

\begin{tabular}{|l|l|l|}
\hline Intervention: & Timings & Duration \\
\hline $\begin{array}{l}\text { Geetam (Raga purvi) } \\
\text { Prandrayama }\end{array}$ & 20 minutes & 15 days \\
\hline
\end{tabular}

\section{Total Study Duration -30 days.}

Patients will be observed before the treatment and the 15 th day after the treatment. Follow up will be done on the 30th day.

\section{STATISTICS}

Statistical analysis was done using SPSS VER.20. Cochran's test and Paired t-test were applied to analyse the significance of the change in subjective parameters. Mc-Nemer test was applied for post hoc which showed significance in Cochran's test, to interpret the time of significant change. Man-witney U test and unpaired t-test were applied for analyzing the significance between Group A and Group B.

\section{OBSERVATIONS}

Out of 40 patients taken for observation, $22.5 \%$ of subjects belonged to the age group of 15 . In group A, the dominant age was 12 . While in group $\mathrm{B}$, a maximum of $35 \%$ belong to 15 years. Among 40 subject's majority of the subjects i.e., 32(80\%) belonged to an upper middle class, $8(20 \%)$ were from the lower middle class. 38(95\%),1(2.5\%) and 1 (2.5) of subjects belonging to Hindu, Muslim and Cristian religions respectively participated in this study. $65 \%$ of the subject in group A and $50 \%$ of the subjects in group B belong to Vatapitta Prakriti. whereas $45 \%$ and $15 \%$ of subjects in group A and B respectively belongs to Pitta kapha Praktiti.Overall 57.5\% of the total subject (40) were of Vatapitta Prakriti. Out of 40 subjects, $65 \%$ were of Avara satwa and 35\% were of Madhyama satwa. Out of forty patients, $25 \%$ had experienced emotional trauma, 5\% of them had a history of exposure to explosive behaviours at home. 


\section{RESULTS}

Table 2: Cochran Test

\begin{tabular}{|c|c|c|c|c|c|c|}
\hline \multicolumn{7}{|l|}{ Group A } \\
\hline & & Mean & Std. Deviation & Frequency & Cochran's Q value & Significance \\
\hline \multirow[t]{3}{*}{ VERBAL AGGRESSION } & BT & 1.00 & .000 & 20 & \multirow{3}{*}{26.375} & \multirow{3}{*}{$<0.001$} \\
\hline & AT & .25 & .444 & 5 & & \\
\hline & FU & .30 & .470 & 6 & & \\
\hline \multirow[t]{3}{*}{ PHYSICAL AGGRESSION } & BT & .75 & .444 & 15 & \multirow[b]{3}{*}{26.143} & \multirow[b]{3}{*}{$<0.001$} \\
\hline & AT & .05 & .224 & 1 & & \\
\hline & FU & .10 & .308 & 2 & & \\
\hline \multirow{3}{*}{$\begin{array}{l}\text { DISPROPORTIONATE TO } \\
\text { MAGNITUDE }\end{array}$} & BT & 1.00 & .000 & 20 & \multirow{3}{*}{32.000} & \multirow{3}{*}{$<0.001$} \\
\hline & AT & .20 & .410 & 4 & & \\
\hline & FU & .20 & .410 & 4 & & \\
\hline \multirow[t]{3}{*}{ DISTRESS } & BT & 1.00 & .000 & 20 & \multirow{3}{*}{34.300} & \multirow[t]{3}{*}{$<0.001$} \\
\hline & AT & .10 & .308 & 2 & & \\
\hline & FU & .05 & .224 & 1 & & \\
\hline
\end{tabular}

Table 3: Cochran Test

\begin{tabular}{|c|c|c|c|c|c|c|}
\hline \multicolumn{7}{|l|}{ Group B } \\
\hline & & Mean & Std. Deviation & Frequency & Cochran's Q value & Significance \\
\hline \multirow{3}{*}{ VERBAL AGGRESSION } & BT & 1.00 & .000 & 20 & \multirow{3}{*}{24.000} & \multirow{3}{*}{$<0.001$} \\
\hline & AT & .25 & .444 & 8 & & \\
\hline & FU & .30 & .470 & 8 & & \\
\hline \multirow[t]{3}{*}{ PHYSICAL AGGRESSION } & BT & .85 & .366 & 17 & \multirow{3}{*}{30.00} & \multirow{3}{*}{$<0.001$} \\
\hline & AT & .10 & .308 & 2 & & \\
\hline & FU & .10 & .308 & 2 & & \\
\hline \multirow{3}{*}{$\begin{array}{l}\text { DISPROPORTIONATE TO } \\
\text { MAGNITUDE }\end{array}$} & BT & 1.00 & .000 & 20 & \multirow{3}{*}{34.111} & \multirow{3}{*}{$<0.001$} \\
\hline & AT & .10 & .308 & 2 & & \\
\hline & FU & .15 & .366 & 3 & & \\
\hline \multirow[t]{3}{*}{ DISTRESS } & BT & 1.00 & .000 & 20 & \multirow{3}{*}{34.000} & \multirow{3}{*}{$<0.001$} \\
\hline & AT & .15 & .366 & 3 & & \\
\hline & FU & .15 & .366 & 3 & & \\
\hline
\end{tabular}

Table 4: Mc Nemar Test

\begin{tabular}{|c|c|c|c|c|c|c|c|}
\hline & & \multicolumn{2}{|c|}{ BT \& AT } & \multicolumn{2}{|c|}{ BT \& FU } & \multicolumn{2}{|c|}{ AT \& FU } \\
\hline SYMPTOMS & & A & B & A & B & A & B \\
\hline $\begin{array}{l}\text { VERBAL } \\
\text { AGGRESSION }\end{array}$ & P-value & .000 & .000 & .000 & .000 & 1.000 & 1.000 \\
\hline $\begin{array}{l}\text { PHYSICAL } \\
\text { AGGRESSION }\end{array}$ & $P$ value & .000 & .000 & .000 & .000 & 1.000 & 1.000 \\
\hline $\begin{array}{l}\text { DISPROPOTIONATE } \\
\text { TO MAGNITUDE }\end{array}$ & $P$ value & .000 & .000 & .000 & .000 & 1.000 & 1.000 \\
\hline DISTRESS & $\mathrm{P}$ value & .000 & .000 & .000 & .000 & 1.000 & 1.000 \\
\hline
\end{tabular}


Table 5: Effect of Geetam Chandra and Anuloma Viloma Paranayama on Buss and Perry Scale

\begin{tabular}{|c|c|c|c|c|c|c|c|c|}
\hline & \multirow[t]{2}{*}{ Mean } & \multirow[t]{2}{*}{$\begin{array}{l}\text { Std. } \\
\text { Deviation }\end{array}$} & \multirow[t]{2}{*}{$\begin{array}{ll}\text { Std. } & \text { Error } \\
\text { Mean } & \end{array}$} & \multicolumn{2}{|c|}{$\begin{array}{l}\text { 95\% Confidence Interval of the } \\
\text { Difference }\end{array}$} & \multirow[t]{2}{*}{$\mathrm{T}$} & \multirow[t]{2}{*}{$\mathrm{df}$} & \multirow[t]{2}{*}{$\begin{array}{l}\text { Sig. } \\
\text { tailed })\end{array}$} \\
\hline & & & & Lower & Upper & & & \\
\hline BT-AT & 51.200 & 19.975 & 4.467 & 41.851 & 60.549 & 11.463 & 19 & .000 \\
\hline BT-FU & 50.250 & 17.502 & 3.913 & 42.059 & 58.441 & 12.840 & 19 & .000 \\
\hline AT-AF & -.950 & 18.426 & 4.120 & -9.574 & 7.674 & -.231 & 19 & .820 \\
\hline \multicolumn{9}{|l|}{ Group B } \\
\hline BT-AT & 59.000 & 19.496 & 4.360 & 49.875 & 68.125 & 13.534 & 19 & .000 \\
\hline BT-FU & 61.450 & 19.176 & 4.288 & 52.475 & 70.425 & 14.331 & 19 & .000 \\
\hline AT-AF & 2.450 & 9.583 & 2.143 & -2.035 & 6.935 & 1.143 & 19 & .267 \\
\hline
\end{tabular}

Table 6: Effect of Treatment between the Groups

\begin{tabular}{|l|l|l|l|l|}
\hline Symptom & Mann-Whitney U & Wilcoxon W & Z & P-value \\
\hline Verbal Aggression & 170.000 & 380.000 & -1.000 & $>0.05$ \\
\hline Physical Aggression & 190.000 & 400.000 & -.350 & $>0.05$ \\
\hline Disproportionate to the magnitude of illness & 180.000 & 390.000 & -.874 & $>0.05$ \\
\hline Distress & 190.000 & 400.000 & -.472 & $>0.05$ \\
\hline
\end{tabular}

Table 7: Independent Samples Test-Buss and Perry Scale

\begin{tabular}{|l|l|l|l|l|l|l|l|l|}
\hline F & Sig. & T & df & $\begin{array}{l}\text { Sig. }(2- \\
\text { tailed })\end{array}$ & $\begin{array}{l}\text { Mean } \\
\text { Difference }\end{array}$ & $\begin{array}{l}\text { Std. Error } \\
\text { Difference }\end{array}$ & \multicolumn{2}{|c|}{$\begin{array}{l}\text { 95\% Confidence Interval } \\
\text { of the Difference }\end{array}$} \\
\hline 002 & .965 & 1.250 & 38 & .219 & -7.800 & 6.241 & -20.435 & 4.835 \\
\hline
\end{tabular}

\section{DISCUSSION}

In the present study effect of Geetam and Chandra anuloma viloma pranayama on Verbal aggression was statistically significant but the variation seen in these two groups were statistically insignificant. In Group A-75\% were improved after treatment. In Group B, $60 \%$ were improved after the treatment.

The effect of Geetam and Chandra anuloma viloma pranayama on Physical aggression was statistically significant but the variation seen in these two groups were statistically insignificant. In Group A-88.23\% were improved after treatment. In Group B, 93.33\% were improved after the treatment

The effect of Geetam and Chandra anuloma viloma pranayama on "Aggressive behaviour which is disproportional to the magnitude of psychosocial stressors" was statistically significant whereas variations seen in these two groups were statistically insignificant. In Group A-90\% were improved after treatment. In Group B, $80 \%$ were improved after the treatment

The effect of Geetam and Chandra anuloma viloma pranayama on "Outburst causes distress or impairment in functioning" was statistically significant but variations seen in these two groups were statistically insignificant. In Group A-90\% were improved after treatment. In Group B, 85\% were improved after the treatment

In a Group Music Intervention Reduces Aggression and Improves Self-esteem in Children with Highly Aggressive Behaviour: A Pilot Controlled Trial, it is found that music can reduce aggressive behaviour and improve self-esteem in children with highly aggressive behaviour. ${ }^{12}$ So, in this study, "Raga Purvi" is used as it pacifies Pitta Dosha. Geeta by virtue of Pitta Shamana property pacifies Pitta, thereby Krodha. Possible mechanisms include relaxation effects $^{13}$, which may modulate the endocrinal responses and stabilize autonomic nervous systems. ${ }^{14}$ 
Geetam intervention also has effects on the brain function resulting in neural network activation, and ultimately leads to activation of different regions of the brain if performed regularly. ${ }^{15}$ These effects also produce better physical and psychological function and therefore have beneficial effects on stress responses; reducing anxiety, improving mood and lessening pain perception.$^{16}$

A study on the relationship between verbal aggressiveness and state anxiety in sports by Alexandra et al. ${ }^{17}$ showed that male basketball players were more affected by the verbal aggressiveness of their coaches compared to female basketball players as assessed by VAS administered immediately after the game. In their study, they also observed a positive correlation between their anxiety and VAS scores in male players. It is known that yoga with its holistic approach uses several techniques to calm down the mind and reduce the anxiety state. Earlier studies have shown that in community homegirls and congenitally blind children, sympathetic tone reduced after yoga practices which resulted in significant decreases in resting heart rates and breath rates, thus reducing fear and anxiety. ${ }^{18}$ The sympathetic tone reduction could be a valuable treatment modality for the reduction of anxiety. Another study on PT teachers also showed that yoga reduced their sympathetic activity after three months of yoga practice. ${ }^{19}$, In a randomized, prospective, single-blind, comparative study has shown the efficacy of Yoga in decreasing verbal aggressiveness. Recent studies have revealed that breathing through a particular nostril can alter metabolism and autonomic activities. In their onemonth-long study, they found that the left nostril Pranayama group also showed an increase of $24 \%$ in baseline oxygen consumption. They attributed this increase in metabolism to increased sympathetic discharge. The 'left nostril Pranayama' group showed an increase in volar galvanic skin resistance, interpreted as a reduction in sympathetic nervous system activity supplying the sweat glands. These results suggest that breathing selectively through either nostril could have a marked activating effect or a relaxing effect on the sympathetic nervous system. ${ }^{21}$
Based on these observations, we may suggest that the reduction in aggressiveness in the present study could be due to the reduction in their baseline anxiety and sympathetic reactivity.

The practitioners of Pranayama try to keep their attention on the act of breathing, leading to concentration. This removes his attention from worldly worries and "de-stress" them. This may decrease the release of adrenaline i.e., decrease sympathetic activity and thereby controlling anger Yogic practices shift the autonomic nervous system balance from primarily sympathetic to parasympathetic, by directly enhancing parasympathetic output, through vagal stimulation, resulting in positive changes in cardiovagal function and associated neuroendocrine, hemodynamic, and inflammatory profiles, in sleep and affect, and in related downstream metabolic parameters.

\section{CONCLUSION}

Krodha is a Manasa Vikara and is considered as Sarvadosha Prakopaka Hetu by Ashtanga Samgraha.This study was intended to compare the efficacy of Geetam and Chandra Anuloma Viloma Pranayama in Krodha. As per the observations, Male subjects were dominant in this study. An evident number of subjects had experienced emotional trauma and had a history of exposure to explosive behaviours at home. As per the result, both Geetam and Chandra Anuloma Viloma Pranayama showed statistically significant results on all the assessment criteria i.e., Buss and Perry scale, Verbal aggression, Physical aggression, Aggressive behaviour is grossly disproportionate to the magnitude of the psychosocial stressors and the outburst that cause distress or impairment of functioning or lead to financial or legal consequences. There is no statistically significant difference observed in the comparison between the 2 groups. Thus, it was concluded that: The null hypothesis is rejected, and the alternative hypothesis (H1) is accepted i.e. There is an equivalent effect of both Geetam and Chandra Anuloma Viloma Pranayama in the management of the Krodha. 


\section{REFERENCES}

1. Adolescent development and participation [Internet]. Unicef.org. [cited 2021 Jun 24]. Available from: https://www.unicef.org/india/what-wedo/adolescentdevelopment-participation

2. Tolan PH, Gorman-Smith D, Loeber R. Developmental timing of onsets of disruptive behaviours and later delinquency of inner-city youth. Journal of Child and Family Studies. 2000;9(2):203-220.

3. Kaplan and Sadock -Victorpff J. Chapter 28.11. In: Benjamin J. Sadock Virginia A. Sadock Pedro Ruiz, editor. Kaplan and Sadock's comprehensive textbook of psychiatry. 9th ed. Philadelphia: Lippincott Williams \& Wilkins; 2009.

4. Sushruta, Sushruta Samhita, with Nibhandha Sangraha commentary by Dalhana, Foreword by Acharya Yadav Ji Trikam Ji, Choukhamba Sanskrit Sansthan: Varanasi; Edition: Reprint 2014, Sutra Sthana Chapter one-third, p6

5. Sushruta, Sushruta Samhita, with Nibhandha Sangraha commentary by Dalhana, Foreword by Acharya Yadav Ji Trikam Ji, Choukhamba Sanskrit Sansthan: Varanasi; Edition: Reprint 2014, Sutra Sthana Chapter 1/3/3.p.6

6. Dr Sadashivasastri. Srimad Bhagavadgita, Shankara bhashya Ramanuja bhavartha, Edited by Rajeswarashastri, Shubham sharma, Published by Chaukhamba Sanskrit samsthan, Edition: Reprint 2013, Chapter 2/63, p91-92

7. Acharya Agnivesha. Charaka Samhita, Ayurveda Deepika Commentary of Chakrapani datta, edited by Vaidya Jadavaji Trikamji Acharya, Published by Chaukhamba Surbharati Prakashan, Edition: Reprint 2008, Nidana Sthana, Chapter $1 / 30$, chakrapami commentary, p.202.

8. Vagbhata. Astanga Hridaya with Commentaries Sarvanga Sundari of Arunadatta and Ayurveda Rasayana of Hemadri, Collected by $\mathrm{Dr}$ Anna Moreshwar Kunte and Edited by Pt. Harisadashiv Shastri Paradkar vaidya, Varanasi: Choukamba Surbharthi Prakashana, Reprint: 2010, Sutra Sthana, Chapter 13/6, p.212

9. Vagbhata. Astanga Hridaya with Commentaries Sarvanga Sundari of Arunadatta and Ayurveda Rasayana of Hemadri, Collected by Dr Anna Moreshwar Kunte and Edited by Pt. Harisadashiv Shastri Paradkar vaidya, Varanasi: Choukamba Surbharthi Prakashana, Reprint: 2010, Sutra Sthana, Chapter 13/6/, p.212

10. Sharan PG. Description of Music Therapy in Ayurved. International Ayurvedic Medical Journal [Internet]. 2017 Aug [cited 2020 Jun 25]; Available from: http://www.iamj.in/posts/images/upload/2901_2905.p df

11. Bhavanani AB. Sarvodaya Vigjnan- A Scientific Study of the Nasal Cycle. Yoga Mimamsa. 2007; 39:32-8.
12. Choi AN, Lee MS, Lee JS. Group Music Intervention Reduces Aggression and Improves Self-esteem in Children with Highly Aggressive Behavior: A Pilot Controlled Trial. Evid Based Complement Alternat Med. 2010;7(2):213-217. doi:10.1093/ecam/nem182

13. 166.Lindblad F, Hogmark A, Theorell T. Music intervention for 5th and 6th graders? Effects on development and cortisol secretion. Stress and Health. 2007; 23:9-14

14. 167.Freeman LW. Physiologic pathways of mind-body communication. In: Freeman LW, Lawlis GF, editors. Mosby's Complementary \& Alternative Medicine: A Research-based Approach. St. Louis, Missouri: Mosby; 2001. pp. 2-33

15. 168.Schmithorst VJ, Holland SK. The effect of musical training on music processing: a functional magnetic resonance imaging study in humans. Neurosci Lett. 2003; 348:65-8.

16. 169.Hillecke T, Nickel A, Bolay HV. Scientific perspectives on music therapy. Ann N Y Acad Sci. 2005; 1060:271-82

17. Bekiari A, Pantazis S, Apostolou M, Nonnati A, Sakellariou K. The relationship between verbal aggressiveness and state anxiety in sport settings. Ital $J$ Sport Sci. 2005; 12:165-8

18. Telles S, Narendran S, Raghuraj P, Nagarathna R, Nagendra HR. Comparison of changes in autonomic and respiratory parameters of girls after Yoga and games at a community home. Percept Motor Skills. 1997; 84:251-7

19. Telles S, Nagarathna R, Nagendra HR, Desiraju T. Physiological changes in sports teachers following 3 months of training in Yoga. Indian J Med Sci. 1993; 10:235-8.

20. Deshpande S, Nagendra HR, Raghuram N. A randomized control trial of the effect of yoga on verbal aggressiveness in normal healthy volunteers. Int $J$ Yoga. 2008;1(2):76-82. doi:10.4103/0973-6131.41034

21. Telles S, Nagarathna R, Nagendra HR. Breathing through a particular nostril can alter metabolism and autonomic activities. Indian J Physiol Pharmacol. 1994 Apr;38(2):133-7. PMID: 8063359.

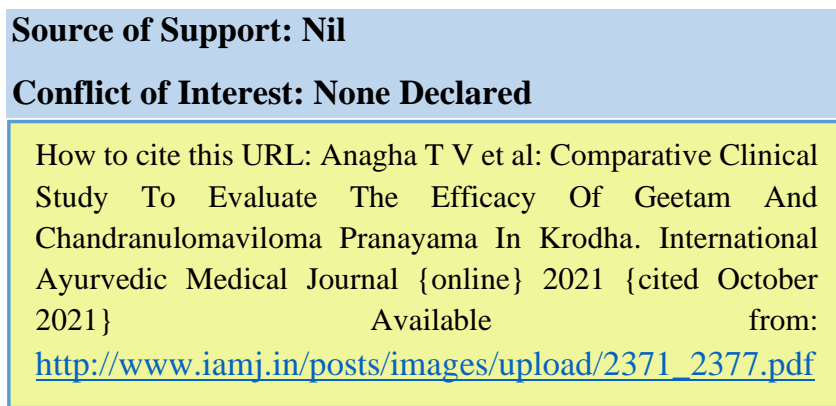

